\title{
Changes in the accounting of property of a construction contractor
}

Irina Zaslavskaya*

Moscow State University of Civil Engineering, Yaroslavskoe shosse, 26, Moscow, 129337, Russia

\begin{abstract}
This article studies the impact of changes in the accounting of property of organizations in connection with the new regulations in the field of accounting, and the convergence of Russian accounting with international standards. These changes are considered on the example of accounting for tools and inventory in a construction contractor. The conclusion is made about the significant impact on the financial statements of the limit for accepting fixed assets for accounting established in the Accounting Policy, and the need to justify the choice of such a limit by the accountant.
\end{abstract}

\section{Introduction}

As a result of the growing trend of convergence of Russian and international accounting, significant changes have taken place in Russian accounting for property, which are caused by the introduction of new Russian Accounting Standards (hereinafter RAS). These changes relate to the accounting of fixed assets, inventories and capital investments.

The new approach to property accounting unambiguously affects the financial statements and, accordingly, most of the financial indicators of the organization.

This article provides an analysis of changes in the accounting of the category of property that is at the "junction" between fixed assets and stocks in a construction contractor. This type of property, for example, includes inventory and inexpensive tools.

Due to the peculiarities of the construction industry, the stocks of a contractor construction organization, as a rule, are presented in almost all types and have the largest share in the cost of construction work. Guided by the general approaches to accounting for reserves, regulated by federal standards, an accountant, nevertheless, should be guided by such distinctive features of a construction contractor's activities as facility accounting, seasonal nature of work, purchase of stocks "on order", the presence of a large volume of inexpensive tools, inventory, overalls and special equipment with a useful life of more than 12 months, etc.

\footnotetext{
* Corresponding author: ivz-mgsu@mail.ru
} 


\section{Literature Review}

From January 1, 2021, inventory accounting should be carried out in accordance with the RAS 5/2019 "Inventories" (hereinafter RAS 5/2019) approved by the Order No. 180n of the Ministry of Finance of the Russian Federation dated November 15, 2019, and made significant changes in the accounting of inventories. This RAS introduced the conditions for the acceptance of property for accounting as inventory and introduced their new classification consisting of eight categories. For the first time, the concepts of "fair value" and "net realizable value of inventory" are used to measure inventories. [5]. The rules for creating and writing off provisions for impairment of material assets have been clarified. In addition, the RAS prescribed new procedures for writing off management costs, which organizations should no longer include in the actual cost of work in progress and finished goods. The accounting of stocks intended for management needs has changed. An entity may choose not to apply the RAS 5/2019 to such inventories, but to write them off as an expense in the current period.

Starting from 2022, there are come into effect Russian Accounting Standards 6/2020 "Fixed assets" (hereinafter FSBU 6/2020) and 26/2020 "Capital investments" (hereinafter FSBU 26/2020) approved by the Order No. 204n of the Ministry of Finance of the Russian Federation dated September 17, 2020. The introduced regulations transform the rules for the identification of property as fixed assets, their classification, valuation and write-off. However, organizations have the right to apply these standards starting from 2021.

In accordance with the order of the Ministry of Finance of the Russian Federation No. 217 n dated December 28, 2015, Russian federal standards introduced the term "fair value", which is determined in the manner prescribed by the International Financial Reporting Standard (IFRS) 13 "Fair Value Measurement". The concept of "fair value" is closely related to the reliability of financial statements. The positions of the new standards are aimed at making the reporting more reliable, and displaying the real state of property and liabilities at the reporting date. [1].

\section{Materials and Methods}

Upon receipt of property in the organization, the accountant immediately faces the question: "To what category of property should this object be attributed?" Property can be accepted for accounting as a fixed asset if the following conditions are simultaneously met (RAS 6/2020), and the property:

- has a material form;

- has intended for use by the organization in the course of its ordinary activities in the production and (or) sale of its products (goods), in the performance of work or in the provision of services, for the protection of the environment, for provision for a fee for temporary use, for management needs, or for use in activities of a non-profit organization aimed at achieving the goals for which it was created;

- is held for use by an entity for a period exceeding 12 months or a normal operating cycle exceeding 12 months;

- is capable of bringing economic benefits (income) to the organization in the future (ensuring that the non-profit organization achieves the goals for which it was created) [5].

In most cases, inventory and tools that meet all of the above characteristics are of low cost. In construction organizations, examples of tools include: a jack, a screwdriver, a hammer, a drill, a shovel, pliers, a gun for polyurethane foam, etc.; examples of inventory: office furniture, laptop, mobile phone, telephone, boxes, boxes, clocks, removable disks, fans, air conditioners, safes, etc. The cost of such property is usually low, and an organization may decide not to account for inventory and tools as fixed assets. 
If earlier the condition for accepting property for accounting as a fixed asset or inventory depended on the limit established by the regulation in the amount of not more than 40 thousand rubles, now the accountant makes a decision being guided only by the level of materiality and rationality of accounting. Even though this rule has been in effect since 2022, the organization can apply it voluntarily from 2021.

Previously, the established criterion of 40 thousand rubles made it possible to take into account inexpensive property as inventory, the validity of which exceeded 12 months. According to the accounting methodology, such property was recognized in accounts 10-9 "Equipment and maintenance accessories "; 10-10 "Special equipment and overall in stock"; 10-11 "Special equipment and overall in service" [2]. For construction contractors, the amount of such property is highly considerable. From 2022, these accounts can only display property that has a validity period of no more than 12 months.

Nevertheless, for accounting for inexpensive property, FSBU 6/2020 offers two options for an organization to choose.

The first option involves the registration as fixed assets of all property, regardless of value, that meets the criteria and has a useful life of more than 12 months. For a construction contractor, this accounting option significantly increases the volume of accounting information and documentation since it implies the use of accounts 01 "Fixed assets", 08 "Investments in non-current assets" and 02 "Depreciation of fixed assets" [2]. In addition, it will become necessary to take into account the difference between accounting and tax accounting since according to the Tax Code, depreciation is charged on property worth more than 100 thousand rubles. [7]. The resulting tax differences will have to be accounted for for each property, plant and equipment valued at less than RUB 100,000 over the entire useful life.

The advantage of this option is an increase in the share of non-current assets in the balance sheet by recognizing all fixed assets. This increases the total of all assets and improves the structure of the balance sheet that provides additional benefits when participating in a tender, obtaining a loan or concluding a profitable construction contract. The considered option is more suitable for small enterprises that do not own large fixed assets.

The RAS 6/2020 also provides for the second option for accounting for inexpensive fixed assets. Unlike the previous establishment, where the limit for classifying property as reserves was approved no more than 40 thousand rubles, now the organization can not only independently set the limit in any amount (taking into account the level of materiality), but also write off all the costs of acquiring such property at once as an expense, rather than being recorded as inventory. As a result, if the limit is set at 100 thousand rubles (in order to avoid discrepancies with the Tax Code), then it is possible not to accrue depreciation and not to carry out transactions through account 10 "Materials". However, in accordance with the requirements of RAS 6/2020, "the organization must ensure proper control of the availability and movement of such assets" [5]. This can be achieved by using off-balance sheet accounts and inventory cards.

The second accounting option greatly simplifies the work of the accounting department, but increases the one-time expenses of the organization in the current period and as a result decreases profits. The property is not recognized in the balance sheet thereby reducing the book value of fixed assets and the amount of assets. If the indicator in the asset of the balance sheet worth 100 thousand rubles is insignificant for the organization, the second option can be applied. Otherwise, the accounting department should lower the limit or abandon it.

Since RAS 6/2020 does not limit the establishment of a fixed asset acceptance limit, an organization can indicate in the Accounting Policy an amount of more or less than 100 thousand rubles. In this case, a difference inevitably arises between accounting and tax accounting. Therefore, it is necessary to have a strong economic justification for the chosen 
limit, and the established amount of the limit must correspond to the level of materiality of the indicators in the balance sheet.

\section{Results}

The selected option for accounting for tools and inventory affects the reporting indicators and the formation of financial results. A comparative analysis of the two accounting options is presented in Table 1.

Table 1. Comparative analysis of accounting of tools and inventory in a construction contractor

\begin{tabular}{|c|c|c|c|c|c|}
\hline \multirow{2}{*}{$\begin{array}{l}\text { Impact on } \\
\text { accounting } \\
\text { and } \\
\text { reporting }\end{array}$} & \multicolumn{2}{|c|}{ Until 2022} & \multicolumn{3}{|c|}{ After 01.01.2022 } \\
\hline & $\begin{array}{l}\text { No price } \\
\text { limit set }\end{array}$ & $\begin{array}{l}\text { The limit is } \\
\text { set at } 40 \\
\text { thousand } \\
\text { rubles }\end{array}$ & $\begin{array}{c}\text { No price limit } \\
\text { set }\end{array}$ & $\begin{array}{l}\text { The limit is } \\
\text { set at } 100 \\
\text { thousand } \\
\text { rubles }\end{array}$ & $\begin{array}{l}\text { The limit is } \\
\text { set at }>100 \\
\text { thousand } \\
\text { rubles }\end{array}$ \\
\hline $\begin{array}{l}\text { Property } \\
\text { category }\end{array}$ & Fixed assets & Stocks & Fixed assets & $\begin{array}{l}\text { Current period } \\
\text { expenses }\end{array}$ & $\begin{array}{c}\text { Current period } \\
\text { expenses }\end{array}$ \\
\hline $\begin{array}{l}\text { Entries in } \\
\text { ledger } \\
\text { accounts }\end{array}$ & $\begin{array}{c}01 \\
\text { "Fixed } \\
\text { assets" } \\
08 \\
\text { "Investment } \\
\text { s in non- } \\
\text { current } \\
\text { assets" } \\
02 \\
\text { "Depreciatio } \\
\text { n of fixed } \\
\text { assets" }\end{array}$ & $\begin{array}{c}10-9 \\
\text { "Equipment } \\
\text { and } \\
\text { maintenance } \\
\text { accessories" } \\
\text { Off-balance } \\
\text { sheet account } \\
\text { when putting } \\
\text { property into } \\
\text { operation }\end{array}$ & $\begin{array}{c}01 \\
\text { "Fixed assets" } \\
08 \\
\text { "Investments } \\
\text { in non-current } \\
\text { assets" } \\
02 \\
\text { "Depreciation } \\
\text { of fixed } \\
\text { assets" }\end{array}$ & $\begin{array}{c}20 \\
\text { "Main } \\
\text { production" } \\
25 \\
\text { "Production } \\
\text { overhead } \\
\text { costs" } \\
26 \\
\text { "General } \\
\text { business } \\
\text { expenses" }\end{array}$ & $\begin{array}{c}20 \\
\text { "Main } \\
\text { production" } \\
25 \\
\text { "Production } \\
\text { overhead } \\
\text { costs" } \\
26 \\
\text { "General } \\
\text { business } \\
\text { expenses" }\end{array}$ \\
\hline $\begin{array}{c}\text { In } \\
\text { tax } \\
\text { accounting }\end{array}$ & $\begin{array}{l}\text { Property up } \\
\text { to } 100 \\
\text { thousand } \\
\text { rubles is } \\
\text { accounted } \\
\text { for with tax } \\
\text { differences }\end{array}$ & $\begin{array}{l}\text { Property from } \\
40 \text { thousand } \\
\text { rubles to } 100 \\
\text { thousand } \\
\text { rubles is } \\
\text { accounted for } \\
\text { with tax } \\
\text { differences }\end{array}$ & $\begin{array}{l}\text { Property up to } \\
100 \text { thousand } \\
\text { rubles is } \\
\text { accounted for } \\
\text { with tax } \\
\text { differences }\end{array}$ & $\begin{array}{c}\text { No } \\
\text { differences }\end{array}$ & $\begin{array}{l}\text { Property over } \\
100 \text { thousand } \\
\text { rubles is } \\
\text { accounted for } \\
\text { with tax } \\
\text { differences }\end{array}$ \\
\hline $\begin{array}{l}\text { Depre- } \\
\text { ciation }\end{array}$ & $\begin{array}{l}\text { Depre- } \\
\text { ciation is } \\
\text { charged }\end{array}$ & $\begin{array}{l}\text { The property } \\
\text { value up to } \\
40 \text { thousand } \\
\text { rubles is } \\
\text { written off } \\
\text { after in- } \\
\text { service date. } \\
\text { Depreciation } \\
\text { is charged on } \\
\text { property over } \\
40 \text { thousand } \\
\text { rubles }\end{array}$ & $\begin{array}{l}\text { Depreciation } \\
\text { is charged }\end{array}$ & $\begin{array}{l}\text { The property } \\
\text { value up to } \\
100 \text { thousand } \\
\text { rubles is } \\
\text { written off } \\
\text { after in- } \\
\text { service date. } \\
\text { Depreciation } \\
\text { is charged on } \\
\text { property over } \\
100 \text { thousand } \\
\text { rubles }\end{array}$ & $\begin{array}{l}\text { The value of } \\
\text { the property } \\
\text { up to the } \\
\text { established } \\
\text { limit is written } \\
\text { off after in- } \\
\text { service date. } \\
\text { Depreciation } \\
\text { is charged on } \\
\text { property over } \\
\text { the } \\
\text { established } \\
\text { limit }\end{array}$ \\
\hline
\end{tabular}




\begin{tabular}{|c|c|c|c|c|c|}
\hline $\begin{array}{c}\text { Impact on } \\
\text { the balance } \\
\text { sheet }\end{array}$ & $\begin{array}{c}\text { Is } \\
\text { recognized } \\
\text { in non- } \\
\text { current } \\
\text { assets, } \\
\text { increases } \\
\text { the balance- } \\
\text { sheet total }\end{array}$ & $\begin{array}{l}\text { Property up to } \\
40 \text { thousand } \\
\text { rubles is } \\
\text { recognized in } \\
\text { current assets, } \\
\text { increases the } \\
\text { balance-sheet } \\
\text { total }\end{array}$ & $\begin{array}{l}\text { Recognized in } \\
\text { non-current } \\
\text { assets, } \\
\text { increases the } \\
\text { balance-sheet } \\
\text { total }\end{array}$ & $\begin{array}{l}\text { Property up to } \\
100 \text { thousand } \\
\text { rubles is not } \\
\text { recognized in } \\
\text { the balance } \\
\text { sheet, the } \\
\text { balance-sheet } \\
\text { total is } \\
\text { reduced }\end{array}$ & $\begin{array}{l}\text { Property } \\
\text { up to the } \\
\text { established } \\
\text { limit is not } \\
\text { recognized in } \\
\text { the balance } \\
\text { sheet, the } \\
\text { balance-sheet } \\
\text { total is } \\
\text { reduced }\end{array}$ \\
\hline $\begin{array}{l}\text { Impact on } \\
\text { the financial } \\
\text { result }\end{array}$ & $\begin{array}{l}\text { Profit is } \\
\text { reduced by } \\
\text { the amount } \\
\text { of } \\
\text { depreciation } \\
\text { deductions }\end{array}$ & $\begin{array}{c}\text { When } \\
\text { property } \\
\text { worth less } \\
\text { than } \\
40 \text { thousand } \\
\text { rubles is put } \\
\text { into operation, } \\
\text { the profit } \\
\text { decreases } \\
\text { at a time }\end{array}$ & $\begin{array}{c}\text { Profit is } \\
\text { reduced by the } \\
\text { amount of } \\
\text { depreciation } \\
\text { deductions }\end{array}$ & $\begin{array}{c}\text { When } \\
\text { property } \\
\text { worth less } \\
\text { than } \\
100 \text { thousand } \\
\text { rubles is put } \\
\text { into operation, } \\
\text { the profit } \\
\text { decreases } \\
\text { at a time }\end{array}$ & $\begin{array}{l}\text { When writing } \\
\text { off expenses } \\
\text { for the } \\
\text { acquisition of } \\
\text { property } \\
\text { within the } \\
\text { established } \\
\text { limit, the } \\
\text { profit is } \\
\text { reduced at a } \\
\text { time }\end{array}$ \\
\hline
\end{tabular}

Assessment of the value of property when accepting it for accounting is a decisive factor in identifying this property as an accounting object: until 2022, this is either a fixed asset or reserves; after 2022, this is either a fixed asset or current period expenses. If there is a limit for acceptance for accounting, then, depending on the formed value, the accountant will be guided by the RAS 5/2019 or the RAS 26/2020 (Table 2).

Table 2. Comparison of the procedure for the formation of the value of property upon acquisition in accordance with the RAS 5/2019 and RAS 26/2020

\begin{tabular}{|c|c|}
\hline $\begin{array}{l}\text { Costs accounted for in acquiring inventory in } \\
\text { accordance with RAS 5/2019 }\end{array}$ & $\begin{array}{l}\text { Costs accounted for in acquiring inventory } \\
\text { in accordance with RAS } 26 / 2020\end{array}$ \\
\hline $\begin{array}{l}\text { The costs paid and (or) payable by the } \\
\text { organization to the supplier (seller, contractor) in } \\
\text { the acquisition (creation) of stocks amount ( } \S 11) \text { : } \\
\text { a) net of refundable taxes and fees; }(\S 12) \\
\text { b) taking into account all discounts, concessions, } \\
\text { deductions, bonuses, benefits provided to the } \\
\text { organization regardless of the form of their } \\
\text { provision }(\S 11) \text {. }\end{array}$ & $\begin{array}{l}\text { Costs paid and (or) payable by the organization } \\
\text { to the supplier (seller, contractor) when making } \\
\text { capital investments amounts }(\S 10) \text { : } \\
\text { a) net of refundable taxes and fees; }(\S 11) \\
\text { б) taking into account all discounts, } \\
\text { concessions, deductions, bonuses, benefits } \\
\text { provided to the organization regardless of the } \\
\text { form of their provision. ( }(11)\end{array}$ \\
\hline $\begin{array}{l}\text { Costs of procurement and delivery of stocks to } \\
\text { the place of their consumption (sale, use) }(\S 12)\end{array}$ & $\begin{array}{l}\text { delivery and bringing the object to the state and } \\
\text { location in which it is suitable for use for the } \\
\text { planned purposes, including its mounting, } \\
\text { installation }(\S 5)\end{array}$ \\
\hline $\begin{array}{l}\text { The cost of bringing inventory to a state in which } \\
\text { it is suitable for use for the planned purposes } \\
\text { ( }(11)\end{array}$ & $\begin{array}{l}\text { Improvement and (or) restoration of an item of } \\
\text { fixed assets }(\S 5)\end{array}$ \\
\hline $\begin{array}{l}\text { The amount of the estimated liability arising in } \\
\text { connection with the acquisition (creation) of } \\
\text { reserves for dismantling, disposal of reserves and } \\
\text { restoration of the environment ( } § 11)\end{array}$ & $\begin{array}{l}\text { The value of the estimated liability arising from } \\
\text { the implementation of capital investments } \\
\text { including for future dismantling, disposal of } \\
\text { property and restoration of the environment, as } \\
\text { well as arising in connection with the use of } \\
\text { labor of employees of the organization }(\S 10)\end{array}$ \\
\hline
\end{tabular}




\begin{tabular}{|c|c|}
\hline $\begin{array}{l}\text { Interest related to the acquisition (creation) of } \\
\text { reserves, which are to be included in the cost of } \\
\text { an investment asset ( }(11)\end{array}$ & $\begin{array}{l}\text { Interest related to the implementation of capital } \\
\text { investments, which are to be included in the } \\
\text { value of the investment asset }(\$ 10)\end{array}$ \\
\hline $\begin{array}{l}\text { Other costs associated with the acquisition } \\
\text { (creation) of inventories ( } \$ 11)\end{array}$ & Other costs $(\S 10)$ \\
\hline $\begin{array}{l}\text { When purchasing stocks on the terms of a } \\
\text { deferral (installment plan) of payment for a } \\
\text { period exceeding } 12 \text { months or a shorter period } \\
\text { established by the organization, the actual cost of } \\
\text { inventories includes the amount of money that } \\
\text { would have been paid by the organization in the } \\
\text { absence of the specified deferral (installment } \\
\text { plan). (\$13) }\end{array}$ & $\begin{array}{l}\text { When making capital investments on the terms } \\
\text { of a deferral (installment plan) of payment for a } \\
\text { period exceeding } 12 \text { months or a shorter period } \\
\text { established by the organization, capital } \\
\text { investments include the amount of money that } \\
\text { would have been paid by the organization in the } \\
\text { absence of the specified deferral (installment } \\
\text { plan) (\$12) }\end{array}$ \\
\hline $\begin{array}{l}\text { When inventories are acquired under contracts } \\
\text { that provide for the fulfillment of obligations } \\
\text { (payment) in full or in part with non-monetary } \\
\text { funds, the costs included in the actual cost of } \\
\text { inventories (in terms of payment in non-monetary } \\
\text { funds) are considered the fair value of the } \\
\text { transferred property, property rights, works, } \\
\text { services. }(\$ 14)\end{array}$ & $\begin{array}{l}\text { When making capital investments under } \\
\text { contracts that provide for the fulfillment of } \\
\text { obligations (payment) in full or in part with } \\
\text { non-monetary funds, the actual costs (in terms } \\
\text { of payment in non-monetary funds) are } \\
\text { considered the fair value of the transferred } \\
\text { property, property rights, works, services. }(\S 13)\end{array}$ \\
\hline $\begin{array}{l}\text { The costs included in the actual cost of } \\
\text { inventories which are received free of charge are } \\
\text { the fair value of those inventories. }(\$ 15)\end{array}$ & $\begin{array}{l}\text { The actual cost of property that the organization } \\
\text { receives free of charge is the fair value of this } \\
\text { property. ( }(14)\end{array}$ \\
\hline
\end{tabular}

The costs taken into account in the formation of the cost of the acquisition of inventories and fixed assets have practically the same components. Forming the initial cost, in both cases the accountant uses similar approaches. If, as a result, the value of an asset exceeds the established limit, it is accepted for accounting as a fixed asset. If the amount is less, it is written off as an expense (when the RAS 6/2020 is applied).

\section{Conclusion}

Starting from 2021, inventory and fixed assets accounting must be carried out in accordance with the requirements of new regulations. With regard to the assets accepted for accounting, there is a possibility of identifying accounting items either as fixed assets or as expenses. This approach differs significantly from the previous accounting rules, when the established limit for accepting fixed assets for accounting was regulated in the amount of 40 thousand rubles (RAS 5/01), and property that met the criteria for a fixed asset but having a value below this amount was accounted for as inventory in the corresponding accounts (10-9 "Equipment and maintenance accessories"; 10-10 "Special equipment and overall in stock"; 10-11 "Special equipment and overall in service") [2].

Applying the new regulations, the organization must prescribe in the Accounting Policy the limit for accepting fixed assets for accounting and independently establish the required level. Thereby, it is necessary to take into account the peculiarities of the economic activity of the organization, the influence of the established limit on the balance sheet indicators and the formation of profit, and also take into account the materiality level.

When forming the initial value of the property, the accountant must take into account the requirements of RAS 5/2019, RAS 6/2020 and RAS 26/2020. Depending on the received amount of actual acquisition costs and the limit set in the Accounting Policy, the property will be accounted for as a fixed asset with subsequent depreciation, or these costs will be written off to the expenses of the current period (if the RAS 6/2020 is applied). 


\section{References}

1. Federalnyy zakon ot 6 dekabrya 2011 g. $\quad$ N $402-\mathrm{FZ}$ «O bukhgalterskom uchete»

2. Prikaz Minfina RF ot 31 oktyabrya 2000 g. N 94n "Ob utverzhdenii Plana schetov bukhgalterskogo ucheta finansovo-khozyaystvennoy deyatelnosti organizatsiy i instruktsii po ego primeneniyu"

3. Prikaz Minfina RF ot 15 noyabrya 2019 g. N 180n "Ob utverzhdenii federalnogo standarta bukhgalterskogo ucheta FSBU 5/2019 'Zapasy"'

4. Prikaz Minfina RF ot 9 iyunya 2001 g. N 44n "Ob utverzhdenii Polozheniya po bukhgalterskomu uchetu 'Uchet materialno-proizvodstvennykh zapasov"' PBU 5/01

5. Prikaz Minfina RF ot 17 sentyabrya 2020 g. N 204n "Ob utverzhdenii federalnykh standartov bukhgalterskogo ucheta FSBU 6/2020 'Osnovnyye sredstva' i FBU 26/2020 'Kapitalnyye vlozheniya"'

6. Prikaz Minfina Rossii ot 28 dekabrya 2015 g. N 217n "O vvedenii Mezhdunarodnykh standartov finansovoy otchetnosti i Razyasneniy Mezhdunarodnykh standartov finansovoy otchetnosti $\mathrm{v}$ deystviye na territorii Rossiyskoy Federatsii i o priznanii utrativshimi silu nekotorykh prikazov (otdelnykh polozheniy prikazov) Ministerstva finansov Rossiyskoy Federatsii" (s izmeneniyami i dopolneniyami)

7. Nalogovyy kodeks Rossiyskoy Federatsii ot 05.08.2000 № 117-FZ

8. Bolokova D.K. Osobennosti ucheta materialno-proizvodstvennykh zapasov v stroitelstve/D.K. Bolokova//Sbornik: Sotsialno-ekonomicheskiye i pravovyye aspekty razvitiya obshchestva. Materialy vserossiyskoy nauchno-prakticheskoy konferentsii. Maykop.- 2020. 56-58

9. Botasheva L.S. Bukhgalterskiy uchet nezavershennogo proizvodstva v stroitelstve//L.S. Botasheva/Vestnik Altayskoy akademii ekonomiki i prava. 2020. № 12-1. 27-32

10. Sklyarova E.V. Problemy bukhgalterskogo ucheta i kontrolya materialnoproizvodstvennykh zapasov v stroitelstve/E.V. Sklyarova L.S. // Sbornik: Problemy sovremennogo obshchestva i puti ikh resheniya. Materialy IIImezhdunarodnoy nauchnoprakticheskoy konferentsii. Pod nauchnoy redaktsiyey M.I. Kutera. 2019. 347-350 